\title{
Upper Sabine River Basin Caddo Mound Sites: The Seaton Bros. (41RA38) and Fruitvale (41VN35) Sites in Rains and Van Zandt Counties, Texas
}

Timothy K. Perttula

Heritage Research Center, Stephen F. Austin State University

Follow this and additional works at: https://scholarworks.sfasu.edu/ita

Part of the American Material Culture Commons, Archaeological Anthropology Commons, Environmental Studies Commons, Other American Studies Commons, Other Arts and Humanities Commons, Other History of Art, Architecture, and Archaeology Commons, and the United States History Commons

Tell us how this article helped you.

This Article is brought to you for free and open access by the Center for Regional Heritage Research at SFA ScholarWorks. It has been accepted for inclusion in Index of Texas Archaeology: Open Access Gray Literature from the Lone Star State by an authorized editor of SFA ScholarWorks. For more information, please contact cdsscholarworks@sfasu.edu. 
Upper Sabine River Basin Caddo Mound Sites: The Seaton Bros. (41RA38) and Fruitvale (41VN35) Sites in Rains and Van Zandt Counties, Texas

\section{Creative Commons License}

\section{(c) (1) \&}

This work is licensed under a Creative Commons Attribution-NonCommercial 4.0 International License 


\title{
Upper Sabine River Basin Caddo Mound Sites: The Seaton Bros. (41RA38) and Fruitvale (41VN35) Sites in Rains and Van Zandt Counties, Texas
}

\author{
Timothy K. Perttula
}

\section{INTRODUCTION}

There are a number of ancestral Caddo-constructed earthen mounds on sites in the upper Sabine River Basin in East Texas (Perttula 1994, 2004:Figure 13.26). Perhaps the best known are the multiple mound centers at the Early Caddo period Boxed Springs site (41UR30) (Perttula 2011; Perttula and Wilson 2000) and the Middle Caddo period Jamestown site (41SM54) (Perttula and Walker 2008; Walters and Perttula 2009). The Seaton Bros. and Fruitvale sites are two of the least known ancestral Caddo mound sites in the upper Sabine River basin (Figure 1).



Figure 1. Locations of the Seaton Bros. (41RA38) and Fruitvale (41VN35) mound sites in East Texas. 
Both sites were recorded by Malone (1972) during the archaeological survey of the proposed Mineola Reservoir, but because the reservoir was not constructed, these mound sites were only investigated during cursory survey efforts. Neither mound site is situated in the Sabine River floodplain or associated alluvial terraces, but had been placed along tributary streams either north or south of the river.

\section{SEATON BROS. (41RA38) SITE}

The Seaton Bros. site was estimated to cover a ca. 30 x $60 \mathrm{~m}$ area, with a knoll at its northern end, and the single constructed mound at its southern end (Figure 2). The mound was estimated at ca. 14-16 m in diameter and $1.9 \mathrm{~m}$ in height.

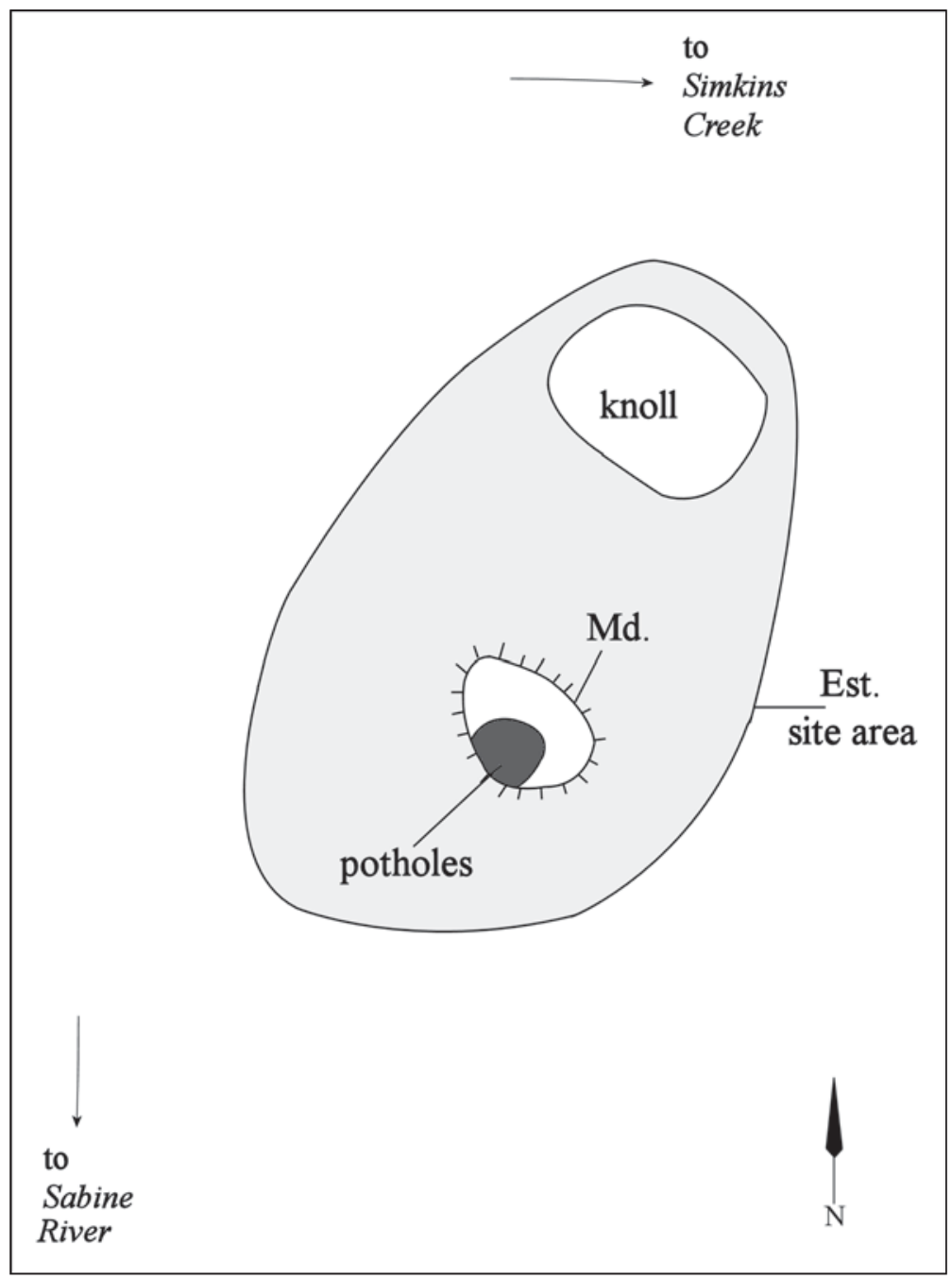

Figure 2. General map of the Seaton Bros. site (41RA38).

The southern part of the mound had been previously looted by the landowners, who reported to Malone that they had recovered ceramic sherds, much daub, mussel shells, and charcoal, along with a long-necked ceramic water bottle; whether the water bottle was decorated or not was not stated by the landowners. The recovery of both daub and a whole ceramic vessel suggests that (1) the Seaton Bros. mound was built to cover an important Caddo grass and thatch-covered structure that had been deliberately burned before it was covered with mound sediments, and (2) it is likely that burials of important Caddo personages may have 
been placed in the structure floor before it was burned, or burials were placed in the mound after it had been constructed. In any case, it is apparent that the Seaton Bros. mound site was the place of an important local Caddo political and religious center.

Artifacts collected from the Seaton Bros. site by Malone included a piece of burned animal bone, two pieces of wood charcoal, 17 pieces of blackened burned clay and daub, a thick early stage petrified wood biface, and 13 Caddo ceramic sherds. Malone noted that the landowners had also sent a box of artifacts from the site to Southern Methodist University, but this collection has not been located and studied to date.

More than 90 percent of the sherds from the site are from grog-tempered vessels, a common characteristic of upper Sabine River basin Caddo ceramic assemblages, among them 11 plain body sherds and two decorated body sherds. One of the body sherds is from a grog-tempered Sanders Plain bottle. As redefined by Brown (1996:401-403 and Figures 2-191, 2-34g, 2-37a-1, 2-38d, 2-39d, k, n-q, and 2-42b), Sanders Plain is a grog-tempered, slipped, and undecorated type found widely across the Caddo area. Vessel forms include bowls, carinated bowls, and narrow and wide-mouthed bottles. The occurrence of a red-slipped vessel in the ceramic sherd assemblage at the Seaton Bros. site is notable because where attribute-level information is available on decorative elements in sherd assemblages, assemblages with considerable amounts of red-slipped sheds are found in the upper Sabine River basin in sites occupied in the Middle Caddo period, along with contemporaneous sites in the middle Red River and the upper Sulphur River basin (Perttula 2015:Figure 3 and Table 1).

The other decorated sherd in the Seaton Bros. collection is a body sherd with rows of fingernail punctations. This sherd is probably from a Monkstown Fingernail Impressed jar (Suhm and Jelks 1962:109 and Plate 55).

\section{FRUITVALE SITE (41VN35)}

The Fruitvale mound site is on an alluvial terrace (400-420 ft. amsl) on the east and southeast sides of Mill Creek, a northern-flowing tributary to the Sabine River a few miles away (Figure 3). The site, including one mound in the southeastern part of the terrace, covers a ca. $100 \times 300 \mathrm{~m}$ area (ca. 7.4 acres).

The mound was estimated by Malone (1972) to be $25 \mathrm{~m}$ in diameter and $2 \mathrm{~m}$ in height. A few looter holes were visible in the mound at the time of Malone's investigations, and these may be the remnants of looting activities that were reported to have taken place at the site in the 1920s. At that time, ancestral Caddo burials and several ceramic vessels had been encountered and removed; the characteristics of these ceramic vessels is not known, nor is their provenience known. If these findings were accurately reported, they suggest that the mound at the Fruitvale site was built to cover and/or contain the burials of the religious and political elite in an ancestral Caddo community in the Post Oak Savanna in the upper Sabine River basin.

The artifact assemblage from the Fruitvale site in the collections at the Texas Archeological Research Laboratory includes only 38 ceramic sherds from Caddo vessels. About 97 percent of the sherds are from grog-tempered vessels. Of the 38 sherds, 35 are plain body $(n=32)$ and base $(n=3)$ sherds. The three decorated sherds are from utility wares with incised decorative elements. One body sherd has parallel incised lines, and another has a single straight incised line. The last incised sherd is from a Canton Incised jar (see Suhm and Jelks 1962:Plate 12d) with diagonal incised lines. The diagonal incised lines begin on the right at the top of the rim and end to the left at the bottom of the rim. Although one decorated rim sherd is not much in the way of substantial archaeological evidence, it does at least suggest that the Fruitvale mound site may have been occupied during some part of the Middle Caddo period. 


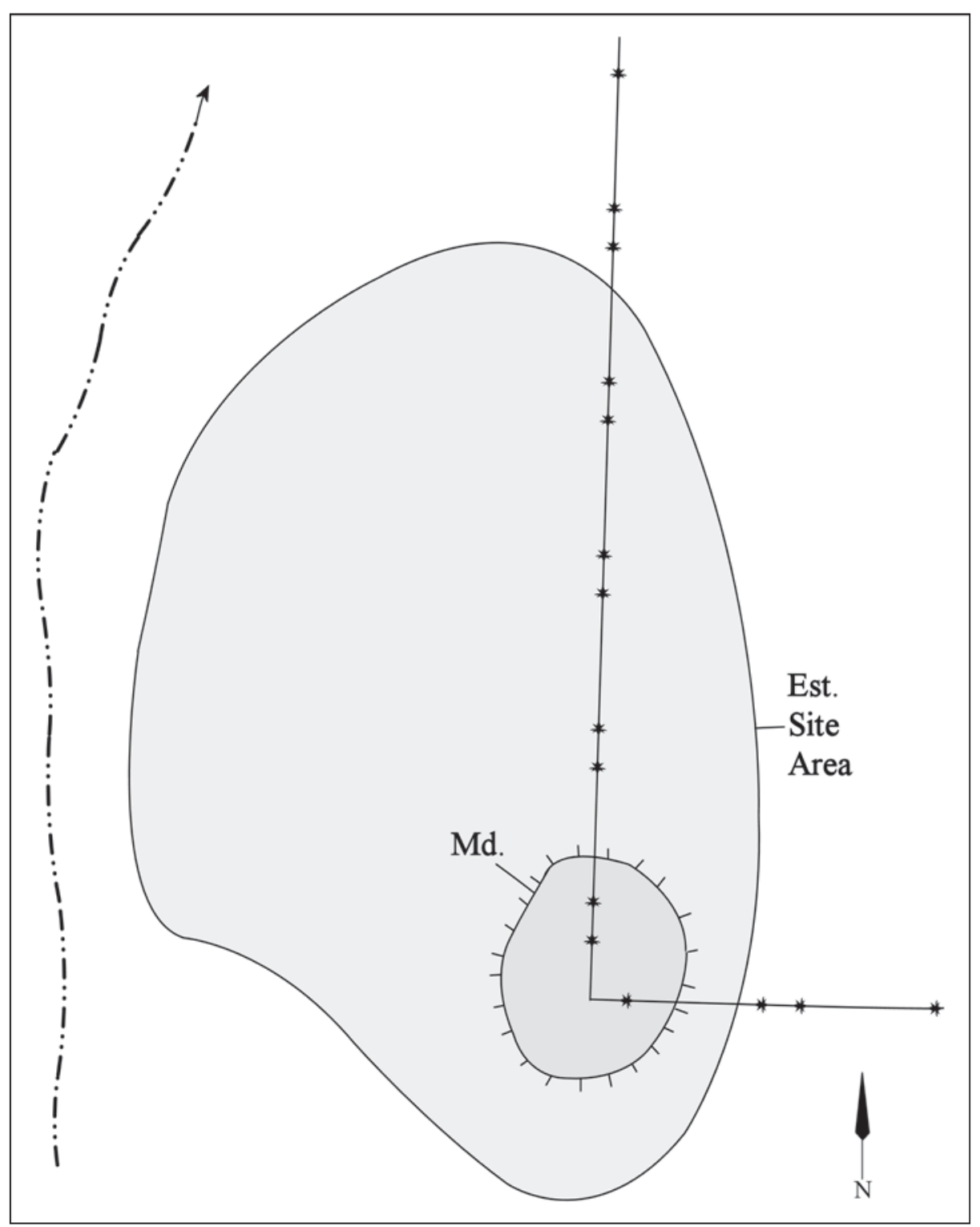

Figure 3. Map of the Fruitvale site (41VN35).

\section{SUMMARY AND CONCLUSIONS}

The Seaton Bros. (41RA38) and Fruitvale (41VN35) sites are ancestral Caddo mound centers in the Post Oak Savannah of the upper Sabine River basin in East Texas. They are poorly known mound centers, but they both warrant renewed archaeological investigations to definitively establish the character of the sites and their ages (through the obtaining and submission of charred plant remain samples for radiocarbon dating), the extent of habitation deposits, and the function and current preservation of the constructed mounds at both sites. The precious little archaeological information available suggests that both mounds may have been constructed to bury and/or contain the graves of important Caddo individuals, while the Seaton Bros. mound was also clearly used to bury an important structure that was burned before it was buried with mound sediments. Material culture remains from the two mound sites are sparse, primarily consisting of plain and decorated sherds from grog-tempered vessels. The identification of sherds from Canton Incised, Monkstown Fingernail Impressed, and Sanders Plain vessels also suggests that both mound sites may have been occupied during the Middle Caddo period (ca. A.D. 1200-1400). 


\section{ACKNOWLEDGMENTS}

I am grateful for the assistance of Jonathan Jarvis at the Texas Archeological Research Laboratory at The University of Texas at Austin in facilitating access to the collections and records from the Seaton Bros. and Fruitvale sites. Lance Trask prepared the figures in the article.

\section{REFERENCES CITED}

Brown, J. A.

1996 The Spiro Ceremonial Center. The Archaeology of Arkansas Valley Caddoan Culture in Eastern Oklahoma. 2 Vols. Memoir No. 29. Museum of Anthropology, University of Michigan, Ann Arbor.

Malone, J. M.

1972 Archaeological Reconnaissance at Proposed Mineola Reservoir. Archeological Survey Report No. 10. Texas Historical Survey Committee, Austin.

Perttula, T. K.

1994 Caddoan Mound Sites in the Sabine River Basin of Northeast Texas. Caddoan Archeology Newsletter 4(4):4-19.

2004 The Prehistoric and Caddoan Archeology of the Northeast Texas Pineywoods. In The Prehistory of Texas, edited by T. K. Perttula, pp. 370-407. Texas A\&M University Press, College Station.

2015 East Texas Caddo Ceramic Sherd Database. Journal of Northeast Texas Archaeology 51:1-46.

Perttula, T. K. (assembler)

2011 Archaeological and Archaeogeophysical Investigations at an Early Caddo Mound Center in the Sabine River Basin of East Texas, Special Publication No. 15. Friends of Northeast Texas Archaeology, Austin and Pittsburg.

Perttula, T. K. and C. P. Walker

2008 The History of Archaeological Investigations and Geophysical Survey at the Jamestown Mound Site (41SM54), an Archaeological Conservancy Preserve in Smith County, Texas. Archeological \& Environmental Consultants, LLC and Archaeo-Geophysical Associates, LLC, Austin.

Perttula, T. K. and D. E. Wilson, with contributions by M. Walters

2000 An Early Caddoan Period Cremation from the Boxed Springs Mound Site (41UR30) in Upshur County, Texas, and a Report on Previous Archaeological Investigations. Journal of Northeast Texas Archaeology 12:31-71.

Suhm, D. A. and E. B. Jelks (editors)

1962 Handbook of Texas Archeology: Type Descriptions. Special Publication No. 1, Texas Archeological Society, and Bulletin No. 4, Texas Memorial Museum, Austin. Reprinted in 2009, Gustav's Library, Davenport, Iowa.

Walters, M. and T. K. Perttula

2009 Recent Documentation of a Profile in Mound A at the Jamestown Mound Site (41SM54), Smith County, Texas. Texas Archeology (Newsletter of the Texas Archeological Society) 53(3):16-17. 